\title{
Genotypic Diversity among Isoniazid-Resistant Isolates of Mycobacterium tuberculosis from Rashid Hospital in Dubai, United Arab Emirates
}

\author{
Suhail Ahmad ${ }^{a}$ Esther Fares ${ }^{b}$ \\ aDepartment of Microbiology, Faculty of Medicine, Kuwait University, Kuwait; b Department of Health and \\ Medical Services, Rashid Hospital, Dubai, UAE
}

\section{Key Words}

Mycobacterium tuberculosis · Isoniazid resistance • Genotyping $\cdot$ katG gene $\cdot$ Dubai

\begin{abstract}
Objective: To perform molecular fingerprinting for strain relatedness among isoniazid-resistant Mycobacterium tuberculosis isolates recovered from tuberculosis (TB) patients in the United Arab Emirates (UAE). Materials and Methods: Thirty-two consecutive isoniazid-resistant M. tuberculosis strains isolated from TB patients (4 natives and 28 expatriates) at Rashid Hospital, Dubai, UAE were analyzed. The typing was carried out by touchdown double-repetitive-element PCR (DRE-PCR). The status of R463 or L463 polymorphism and the presence of S315T mutation in the katG gene were also determined for isolates exhibiting cluster pattern in DRE-PCR. Results: All the 32 isolates (28 from expatriate patients and 4 from UAE nationals) exhibited 21 distinct patterns in DRE-PCR with 20 of 32 isolates exhibiting unique patterns and the remaining 12 exhibiting cluster ' $A$ ' pattern. All the isolates (19 of 19) yielding two or more DNA fragments in DRE-PCR were unique strains. The genotypic heterogeneity among 10 of the 12 cluster isolates was suggested by the varying susceptibility of these isolates to anti-TB
\end{abstract}

\section{KARGER}

Fax +4161306 1234

E-Mail karger@karger.ch

www. karger.com

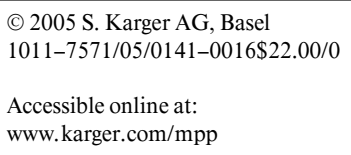

drugs, presence of R463 or L463 polymorphism in the kat $G$ gene and the presence or absence of S315T mutation in the katG gene. Conclusion: The genotypic diversity among isoniazid-resistant $M$. tuberculosis isolates mostly recovered from expatriate patients indicates that most expatriates were infected with a unique strain imported, most likely, from their country of origin and that their latent infection was reactivated in UAE.

Copyright $\odot 2005$ S. Karger AG, Basel

\section{Introduction}

Tuberculosis (TB) caused primarily by Mycobacterium tuberculosis is an infectious disease of global significance. It is estimated that nearly 2 billion people are already infected with $M$. tuberculosis, 8 million individuals develop active disease and nearly 2 million people die of TB each year, mostly in developing but also in developed countries [1]. The emergence and spreading of drug-resistant strains of $M$. tuberculosis has become a major obstacle in the control and management of TB [2]. A better understanding of transmission patterns will help to control the spread of infections, particularly involving drugresistant strains of $M$. tuberculosis. Clinical isolates of $M$. tuberculosis are usually differentiated by Southern blot-
Dr. Suhail Ahmad

Department of Microbiology, Faculty of Medicine

Kuwait University, PO Box 24923

13110 Safat (Kuwait)

Tel. +965 531 2300, ext. 6503, Fax +965 531 8454, E-Mail suhail_ah@hsc.edu.kw 
ting of genomic DNA with insertion sequence IS6110, poly-GC-rich sequence (PGRS) or other repetitive elements as a probe [3]. The double-repetitive-element PCR (DRE-PCR) is a rapid typing method based on amplification of segments of DNA located between two repetitive elements (IS6110 and PGRS) on the genome [4, 5].

Although isoniazid is the most potent anti-TB drug, resistance to this drug also develops readily and isoniazidresistant $M$. tuberculosis strains remain infectious. Thus, improper treatment of infections with isoniazid-resistant strains may lead to further development and spreading of multidrug-resistant strains of $M$. tuberculosis [6]. The resistance of $M$. tuberculosis to isoniazid is caused by mutations in several genes, although, clinically relevant resistance is usually due to mutations within the katG gene, particularly involving codon 315 [7]. However, polymorphism at codon 463 (R463 or L463) in the katG gene is found in both isoniazid-susceptible and -resistant M. tuberculosis strains [7, 8].

Dubai, like many urban centers in the United Arab Emirates (UAE) and other Arabian countries in the Persian Gulf region, has a large expatriate population originating from countries where TB is endemic $[8,9]$. All expatriates entering UAE are screened for TB (chest radiogram) and visa is granted only to individuals with no active disease. In 1998, the notification rate of TB for the entire population in UAE was reported as 28 cases per 100,000 population [9]. Nearly $85 \%$ of TB cases in urban centers of UAE occur in the expatriate population with $15 \%$ of $M$. tuberculosis isolates being resistant to isoniazid [9]. The Rashid Hospital in Dubai, UAE, with 500 beds is a major reference hospital of the Government of Dubai where active TB cases are also diagnosed and treated. The aim of this study was to determine whether infection with isoniazid-resistant $M$. tuberculosis strains in Dubai was due to spreading of epidemic strains so that appropriate control measures could be instituted.

\section{Materials and Methods}

\section{Clinical M. tuberculosis Isolates}

A total of 32 consecutive isoniazid-resistant strains of $M$. tuberculosis isolated from TB patients at Rashid Hospital, Dubai (representing all isoniazid-resistant strains obtained from January 1999 to January 2001) were analyzed. Seven drug-susceptible strains of $M$. tuberculosis isolated during the same period were also analyzed. Only 4 isolates were recovered from local patients (UAE nationals) while 28 isolates were obtained from expatriate workers or their dependents (table 1). Thirty-one of the 32 patients were adults between 18 and 65 years of age, and 28 of them were male patients. Isolation, identification and drug susceptibility testing were performed using the BACTEC system as reported earlier [10]. The anti-TB drugs were isoniazid, rifampin, streptomycin and ethambutol. The isolates were considered resistant when bacterial growth occurred at a concentration of $0.1 \mu \mathrm{g}$ isoniazid per milliliter, $2 \mu \mathrm{g} / \mathrm{ml}$ rifampin or streptomycin, and $2.5 \mu \mathrm{g} / \mathrm{ml}$ ethambutol.

\section{Typing by Touchdown DRE-PCR}

Touchdown DRE-PCR was performed for typing the 32 consecutive isoniazid-resistant $M$. tuberculosis isolates and the status of polymorphism at codon 463 as well as the presence of S315T mutation in the $k a t G$ gene were also determined for isolates exhibiting cluster pattern. The genomic DNA, prepared from M. tuberculosis $\mathrm{H}_{37} \mathrm{Rv}$ and isoniazid-resistant clinical isolates of $M$. tuberculosis as described previously [5], was used as template in DRE-PCR. The DNA sequences of the four primers used in DRE-PCR were as follows: IS6110-5'R， 5'-GGCTGAGGTCTCAGATCAGAG; IS6110-3'F, 5'-ACCCCATCCTTTCCAAGAACT; PGRS-5'R, 5'-TCCCCGCCGTTGCCGTACAG and PGRS-3'F, 5'-CTTGGGAAACCCGGCCAGCTG. The modified touchdown DRE-PCR was performed as described previously [5]. Briefly, the reaction mixtures in a final volume of $50 \mu \mathrm{l}$ contained $\times 1$ Perkin-Elmer PCR buffer II, $2.5 \mathrm{mM}$ $\mathrm{MgCl}_{2}, 10 \mathrm{pmol}$ each of the four primers, $4 \mu \mathrm{l}$ of template DNA, $0.2 \mathrm{~m} M \mathrm{dNTP}$ and two units of AmpliTaq DNA polymerase. The amplified product $(20-25 \mu \mathrm{l})$ was run on $2 \%$ agarose gels and the isolates that yielded varying DNA amplified fragments were considered as genotypically distinct strains.

\section{Detection of R463/L463 Polymorphism in the katG Gene}

The presence of arginine or leucine at codon 463 (R463 or L463) within the $\mathrm{kat} G$ gene in isoniazid-resistant $M$. tuberculosis isolates was determined by amplification of the $k a t G$ gene DNA region around codon 463 by PCR followed by restriction endonuclease digestion of the PCR-amplified fragment with $\mathrm{NciI}$ to generate restriction fragment length polymorphism (RFLP), as described previously [8].

Detection of S315T Mutation in the katG Gene

The presence of S315T substitution, the most common genetic alteration in the $k a t G$ gene in isoniazid-resistant M. tuberculosis isolates, was also determined for the isolates exhibiting cluster pattern in DRE-PCR. This was achieved by amplification of the corresponding $k a t G$ gene DNA region by PCR followed by restriction endonuclease digestion of the PCR-amplified fragments with $M s p$ I to generate RFLP as described previously [11].

\section{Results}

The clinical background and resistance patterns of the 32 isoniazid-resistant clinical M. tuberculosis isolates recovered from TB patients in Dubai, UAE, are presented in table 1 . Nine isolates were resistant to isoniazid only, 12 isolates were resistant to one more drugs, 8 were resistant to two other drugs and 3 were resistant to all the four anti-TB drugs (table 1). Eleven isolates were multidrugresistant TB strains (resistant at least to isoniazid and rifampin). 
Table 1. Clinical background and genotyping patterns by DRE-PCR of the 32 isoniazid-resistant clinical $M$. tuberculosis isolates from Dubai

\begin{tabular}{|c|c|c|c|c|c|c|}
\hline $\begin{array}{l}\text { Isolate } \\
\text { No. }\end{array}$ & $\begin{array}{l}\text { Year of } \\
\text { isolation }\end{array}$ & $\begin{array}{l}\text { Specimen } \\
\text { cultured }\end{array}$ & $\begin{array}{l}\text { Resistance } \\
\text { pattern }\end{array}$ & $\begin{array}{l}\text { Patient's } \\
\text { nationality }\end{array}$ & Sex & $\begin{array}{l}\text { DRE-PCR } \\
\text { pattern }\end{array}$ \\
\hline DH1 & 1999 & sputum & $\mathrm{H}, \mathrm{E}$ & Indian & male & 'A' pattern \\
\hline $\mathrm{DH} 2$ & 1999 & sputum & $\mathrm{H}, \mathrm{E}, \mathrm{S}$ & Indian & male & 'A' pattern \\
\hline DH3 & 1999 & pleural fluid & $\mathrm{H}$ & UAE & female & unique \\
\hline DH4 & 1999 & sputum & $\mathrm{H}, \mathrm{S}$ & Indian & male & 'A' pattern \\
\hline DH5 & 1999 & sputum & $\mathrm{H}, \mathrm{R}$ & Indian & male & 'A' pattern \\
\hline DH6 & 1999 & sputum & $\mathrm{H}, \mathrm{R}$ & Yemani & male & unique \\
\hline DH7 & 1999 & pus swab & $\mathrm{H}, \mathrm{E}, \mathrm{S}$ & Indian & male & 'A' pattern \\
\hline DH8 & 1999 & sputum & $\mathrm{H}$ & UAE & female & unique \\
\hline DH9 & 1999 & pus swab & $\mathrm{H}, \mathrm{E}, \mathrm{R}$ & UAE & female & unique \\
\hline DH10 & 1999 & pleural fluid & $\mathrm{H}$ & Indian & male & 'A' pattern \\
\hline DH11 & 1999 & abscess & $\mathrm{H}$ & Indian & male & unique \\
\hline DH12 & 1999 & sputum & $\mathrm{H}, \mathrm{S}, \mathrm{R}$ & Bangladeshi & male & 'A' pattern \\
\hline DH13 & 2000 & pleural fluid & $\mathrm{H}$ & Indian & male & 'A' pattern \\
\hline DH14 & 2000 & pus swab & $\mathrm{H}$ & Pakistani & male & 'A' pattern \\
\hline DH15 & 2000 & lymph node & $\mathrm{H}$ & Pakistani & female & unique \\
\hline DH16 & 2000 & pus swab & $\mathrm{H}$ & Bangladeshi & male & unique \\
\hline DH17 & 2000 & pus swab & $\mathrm{H}, \mathrm{R}$ & Indian & male & 'A' pattern \\
\hline DH18 & 2000 & sputum & $\mathrm{H}, \mathrm{R}$ & Russian & male & unique \\
\hline DH19 & 2000 & sputum & $\mathrm{H}, \mathrm{E}$ & UAE & male & 'A' pattern \\
\hline DH20 & 2000 & pus swab & $\mathrm{H}, \mathrm{E}, \mathrm{S}$ & Filipino & male & unique \\
\hline DH21 & 2000 & sputum & $\mathrm{H}, \mathrm{E}, \mathrm{S}, \mathrm{R}$ & Pakistani & male & unique \\
\hline DH22 & 2000 & sputum & $\mathrm{H}, \mathrm{E}, \mathrm{S}, \mathrm{R}$ & Indian & male & unique \\
\hline DH23 & 2000 & sputum & $\mathrm{H}, \mathrm{E}, \mathrm{S}, \mathrm{R}$ & Somalian & male & unique \\
\hline DH24 & 2000 & pus swab & $\mathrm{H}, \mathrm{S}, \mathrm{R}$ & Somalian & male & unique \\
\hline DH25 & 2000 & pus swab & $\mathrm{H}, \mathrm{S}, \mathrm{R}$ & Somalian & male & unique \\
\hline DH26 & 2000 & pleural fluid & $\mathrm{H}, \mathrm{E}, \mathrm{S}$ & Indian & male & unique \\
\hline $\mathrm{DH} 27$ & 2000 & CSF & $\mathrm{H}$ & Indian & female & 'A' pattern \\
\hline DH28 & 2001 & BAL & $\mathrm{H}, \mathrm{E}$ & Nepali & male & unique \\
\hline DH29 & 2001 & pus swab & $\mathrm{H}, \mathrm{E}$ & Indian & male & unique \\
\hline DH30 & 2001 & pleural fluid & $\mathrm{H}, \mathrm{E}$ & Indian & male & unique \\
\hline DH31 & 2001 & lymph node & $\mathrm{H}, \mathrm{E}$ & Pakistani & male & unique \\
\hline DH32 & 2001 & pleural fluid & $\mathrm{H}, \mathrm{E}$ & Indian & male & unique \\
\hline
\end{tabular}

$\mathrm{CSF}=$ Cerebrospinal fluid; $\mathrm{BAL}=$ bronchoalveolar lavage; $\mathrm{H}=$ isoniazid $; \mathrm{E}=$ ethambutol; $\mathrm{S}=$ streptomycin; $\mathrm{R}=$ rifampin.

The agarose gel electrophoresis patterns for 15 selected isolates are shown in figure 1. A single DNA fragment was obtained from 13 isolates and two different patterns were apparent (fig. 1, lanes 1 and 3) with most of the isolates (12 strains) yielding a single DNA fragment of the same size $(360 \mathrm{bp}$ ) as shown in figure 1 , lane 1 . This DRE-PCR pattern (fig. 1, lane 1) was labeled as 'A' pattern.

Nineteen isolates yielded two or more DNA fragments and all of these isolates exhibited unique patterns (the patterns for 13 isolates are depicted in fig. 1, lanes 2, 4-15). Thus, the 32 isoniazid-resistant isolates exhibited 21 dis- tinct patterns in DRE-PCR with 20 of them being unique patterns while 12 isolates exhibited 'A' pattern. All the isolates recovered from patients originating from Yemen, Russia, Philippines, Nepal and Somalia exhibited unique patterns (table 1); 3 of 4 isolates from UAE nationals also exhibited unique patterns. Similarly, 3 of 4, 6 of 15 and 1 of 2 isolates recovered from patients originating from Pakistan, India and Bangladesh, respectively, exhibited unique patterns. The remaining isolates yielded ' $A$ ' pattern in DRE-PCR (table 1). When the 7 drug-susceptible strains were analyzed, 2 of 3 isolates recovered from 


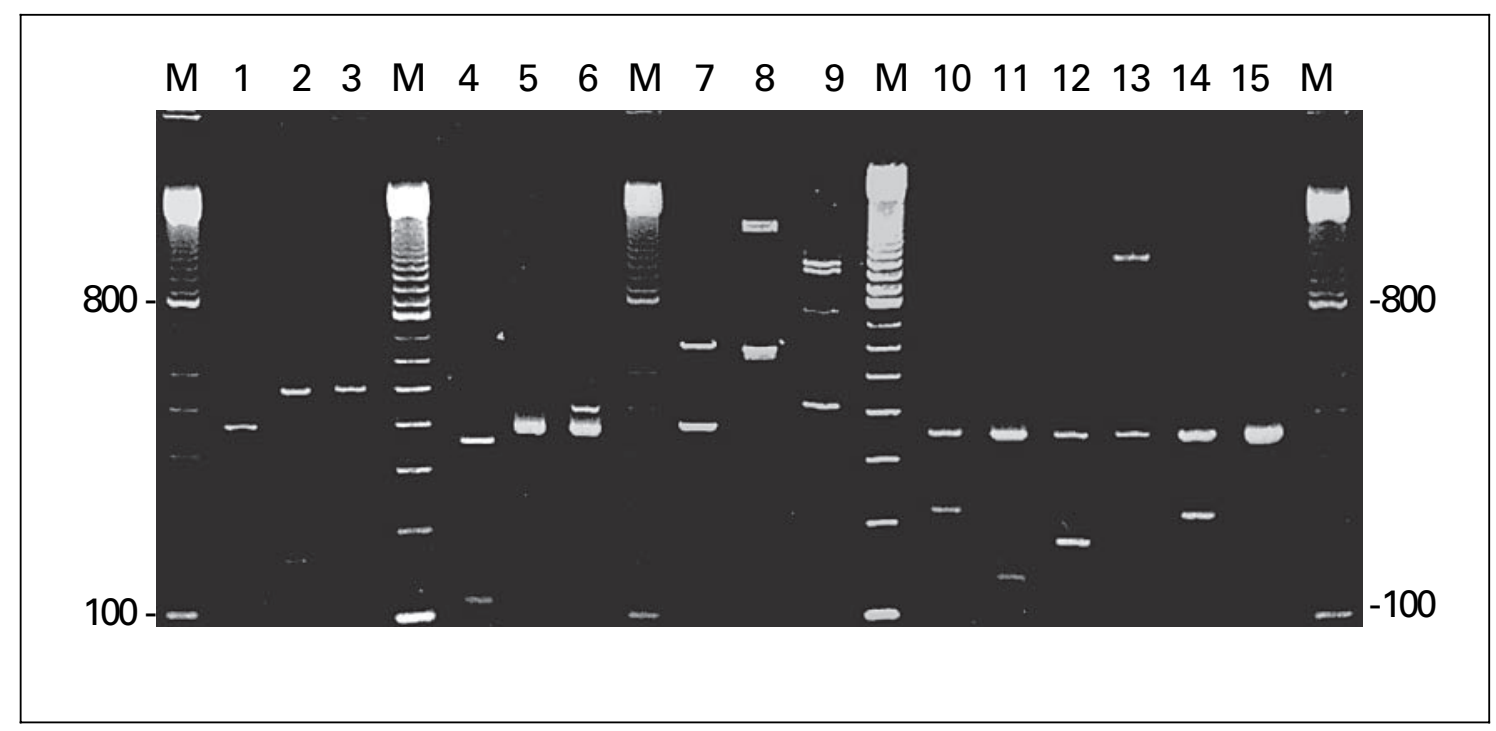

Fig. 1. The DNA fragment patterns in agarose gel from 15 selected isoniazid-resistant $M$. tuberculosis isolates during typing by touchdown DRE-PCR. Twelve isolates yielded a single DNA fragment of the same size ( $360 \mathrm{bp}$, labeled as 'A' pattern and shown for one isolate in lane 1) while the remaining 20 isolates yielded one or more unique DNA fragments (the patterns for 14 isolates are shown in lanes 2-15). Lane M is 100-bp DNA ladder and the positions of migration of 100- and 800-bp fragments are marked.

patients originating from India also exhibited 'A' DREPCR pattern (data not shown).

The genotypic relationship among 'A' cluster pattern isolates was further evaluated by incorporating the data on resistance patterns, R463 or L463 polymorphism and presence or absence of $\mathrm{S} 315 \mathrm{~T}$ mutation in the $k a t G$ gene. These analyses showed that 4 of 12 isolates contained R463 while the remaining isolates contained L463 in the $k a t G$ gene. The S315T mutation was also present in 7 of 12 isolates (table 2). However, when all the 12 isolates were analyzed for drug resistance pattern, amino acid at codon 463 and S315T substitution in the $k a t G$ gene, only 2 isolates (DH10 and DH13) recovered from the 2 patients of Indian origin were found identical (table 2).

\section{Discussion}

The Rashid Hospital, Dubai, UAE, is a major reference hospital and one of the hospitals/area clinics where active TB cases are diagnosed and treated. Of the 32 patients from whom the isoniazid-resistant $M$. tuberculosis isolates were obtained, only 4 patients were UAE nationals while the rest were expatriate workers or their dependents originating from countries where TB is en-
Table 2. Genotypic heterogeneity among isolates exhibiting a single DNA fragment of the same size (360 bp, 'A' cluster pattern) in DREPCR

\begin{tabular}{lllll}
\hline $\begin{array}{l}\text { Isolate } \\
\text { No. }\end{array}$ & $\begin{array}{l}\text { Resistance } \\
\text { pattern }\end{array}$ & $\begin{array}{l}\text { Country } \\
\text { of origin }\end{array}$ & $\begin{array}{l}\text { Amino acid } \\
\text { at codon 463 }\end{array}$ & $\begin{array}{l}\text { S315T } \\
\text { substitution }\end{array}$ \\
\hline DH1 & H,E & India & L463 & $\begin{array}{l}\text { absent } \\
\text { absent }\end{array}$ \\
DH2 & H, E, S & India & R463 & present \\
DH4 & H, S & India & L463 & absent \\
DH5 & H, R & India & L463 & present \\
DH7 & H, E, S & India & R463 & present \\
DH10 & H & India & L463 & present \\
DH12 & H, S, R & Bangladesh & L463 & present \\
DH13 & H & India & L463 & absent \\
DH14 & H & Pakistan & L463 & present \\
DH17 & H, R & India & L463 & absent \\
DH19 & H, E & UAE & R463 & present \\
DH27 & H & India & R463 & \\
\hline
\end{tabular}

demic. The data strongly suggest that isoniazid-resistant M. tuberculosis infections in Dubai, UAE, are mainly associated with expatriate workers or their dependents.

The typing of 32 isoniazid-resistant $M$. tuberculosis isolates exhibited a total of 21 distinct patterns with 20 of them being unique patterns while 12 isolates exhibited 
cluster ('A') pattern. Nine of $12 \mathrm{M}$. tuberculosis isolates exhibiting ' $A$ ' pattern were recovered from patients originating from India. The DNA fragment patterns in DREPCR depend on the copy number and relative positions of repetitive elements IS6110 and PGRS on the $M$. tuberculosis genome [3]. Thus, the amplification of a single DNA fragment from ' $A$ ' cluster pattern isolates may indicate low copy numbers of these repetitive elements. Alternatively, the isolates may represent a genuine cluster implying recent transmission. The copy number of repetitive element IS6110 varies widely among clinical M. tuberculosis isolates [3] and nearly $50 \%$ of the isolates from India are known to contain less than two copies of IS 6110 on their genome $[12,13]$. The data on resistance pattern, R463 or L463 polymorphism and presence or absence of S315T mutation in the katG gene showed genotypic heterogeneity among ' $A$ ' cluster pattern isolates. Although altering of drug resistance patterns of $M$. tuberculosis isolates does not lead to a change in IS6110based fingerprints [3], the strains spreading locally are expected to exhibit similar polymorphism at codon 463 of the $k a t G$ gene $[8,14]$. Further, two of three drug-susceptible strains of $M$. tuberculosis, recovered from patients of Indian origin, also yielded 'A' DRE-PCR pattern. Taken together, the amplification of a single DNA fragment in DRE-PCR from some of the isolates exhibiting 'A' pattern is most likely due to low copy number of IS6110. However, the possibility that some of the cluster isolates were genotypically related, could not be completely ruled out.

Molecular epidemiological studies for TB are carried out to ascertain the transmission of $M$. tuberculosis and are based on the assumption that strains derived recently from a common ancestor exhibit the same fingerprint (cluster pattern) [15]. The term cluster is used to denote $M$. tuberculosis isolates with identical or nearly identical DNA fingerprints [3, 16]. In most low-incidence countries for TB, the typing patterns of $M$. tuberculosis are highly polymorphic due to reactivation of previously acquired infection in the majority of indigenous populations (a reflection of genotypes present in the population over a long period of time) and infection with strains novel to the areas that are imported from the country of origin by expatriate/immigrant populations $[3,16]$. On the contrary, in countries with a high incidence of TB, the typing patterns are often less variable due to recent acquisition of infection in a sizeable portion of the population [17]. The incidence of TB is low in UAE ( 28 cases per 100,000 population) and directly observed chemotherapy short course as recommended by the World Health Organization is fol- lowed for all patients diagnosed with active disease [9]. Since all the expatriates are screened for TB upon entry into UAE, the active disease in local or expatriate patients could either be due to recent acquisition of infection or due to reactivation of latent infection. The typing carried out by touchdown DRE-PCR, the data on polymorphism at codon 463 in the $k a t G$ gene and the presence/absence of S315T mutation in the katG gene showed that most TB patients in Dubai were infected with a unique strain of $M$. tuberculosis. The genetic diversity exhibited by the majority of isoniazid-resistant isolates of $M$. tuberculosis suggests that active disease in most of the patients was likely due to reactivation of latent infection and not due to recent transmission. Although the data on the length of stay in UAE for the expatriates was not available, molecular evidence has recently shown that endogenous reactivation resulting in active disease may occur even after 33 years of latent infection [18].

Recent data from Kuwait, another Arabian country in the Persian Gulf region which also has a large expatriate population originating from TB endemic countries of South Asia and Southeast Asia, have also shown that the majority of isoniazid-resistant $M$. tuberculosis infections occur in the expatriate population [11, 19]. Further, similar to the data reported here, most of the isoniazid-resistant $M$. tuberculosis strains from Kuwait also exhibited unique patterns in typing studies [5, 11]. Molecular epidemiological data from the United States of America (USA) have also shown that active disease in the majority of foreign-born patients is caused by reactivation of latent $M$. tuberculosis infection while many TB cases among USA-born persons are attributed to recent transmission of infection [20]. The reactivation of latent infection in immigrants originating from endemic countries may introduce novel strains among local populations in low-incidence countries. The reactivation of latent $M$. tuberculosis infection with drug-resistant strains in Russian immigrants and their subsequent spread to the local population were recently shown in Germany [21]. These studies have suggested treatment of latent infection in immigrants from endemic countries to avert the introduction of novel strains in low-incidence countries [18, 20,21].

\section{Conclusion}

The results presented in this study showed that most infections with isoniazid-resistant strains of $M$. tuberculosis in Dubai, UAE were associated with expatriates. The 
genotypic heterogeneity exhibited by most of the isolates suggests that most expatriate patients were infected with a unique strain most probably imported from their country of origin and that their latent infection was reactivated in Dubai.

\section{Acknowledgment}

This study was supported in part by Kuwait University Research Administration Grant MI 116.

\section{References}

1 Dye C, Scheele S, Dolin P, Pathania V, Raviglione MC for the WHO Global Surveillance and Monitoring Project: Global burden of tuberculosis: Estimated incidence, prevalence, and mortality by country. JAMA 1999;282: 677-686.

$\checkmark 2$ Espinal MA, Laszlo A, Simonsen L, Bouhlabal F, Kim SJ, Reniero A, Hoffner S, Rieder HL, Binkin N, Dye C, Williams R, Raviglione MC for the World Health Organization-International Union against Tuberculosis and Lung Disease working group on anti-tuberculosis drug resistance surveillance: Global trends in resistance to antituberculosis drugs. $\mathrm{N}$ Engl J Med 2001;344:1294-1303.

$\checkmark 3$ Van Soolingen D: Molecular epidemiology of tuberculosis and other mycobacterial infections: Main methodologies and achievements. J Intern Med 2001;249:1-26.

4 Friedman CR, Stoeckle MY, Johnson WD, Riley LW. Double-repetitive-element PCR method for subtyping Mycobacterium tuberculosis clinical isolates. J Clin Microbiol 1995;33: 1383-1384.

$\checkmark 5$ Mokaddas E, Ahmad S, Abal AT: Molecular fingerprinting of isoniazid-resistant Mycobacterium tuberculosis isolates from Chest Diseases Hospital in Kuwait. Microbiol Immunol 2002;46:767-771.

$\checkmark 6$ Hyem B, Honoroe N, Truffot-Pernot C, Banerjee A, Schurra C, Jacobs WR Jr, van Embden JDA, Grosset JH, Cole ST: The implications of multi-drug resistance for the future of shortcourse chemotherapy of tuberculosis: A molecular study. Lancet 1994;344:293-298.

7 Ramaswamy S, Musser JM: Molecular genetic basis of antimicrobial agent resistance in $\mathrm{Myco}$ bacterium tuberculosis: 1998 update. Tuber Lung Dis 1998;79:3-29.
8 Ahmad S, Abal AT, Mokaddas E, Araj GF, Fares E, Mustafa AS: Genetic polymorphism at codon 463 in the kat $G$ gene in isoniazid sensitive and resistant isolates of Mycobacterium tuberculosis. Med Princ Pract 2001;10:129_ 134

9 Dissanayake S, Usmani A, Sheikh FA, SheekHussein M, Ameen AM, Lukic ML: Mycobacterium tuberculosis in the United Arab Emirates: Evidence of local transmission with unique strains. Trans R Soc Trop Med Hyg 2001;95:591-594.

10 Ahmad S, Araj GF, Akbar PK, Fares E, Chugh TD, Mustafa AS: Characterization of rpoB mutations in rifampin-resistant Mycobacterium tuberculosis isolates from the Middle East. Diagn Microbiol Infect Dis 2000;38:227-232.

11 Abal AT, Ahmad S, Mokaddas E: Variations in the occurrence of the S315T mutation within the kat $G$ gene in isoniazid-resistant clinical Mycobacterium tuberculosis isolates from $\mathrm{Ku}-$ wait. Microb Drug Resist 2002;8:99-105.

12 Das S, Paramasivan CN, Lowrie DB, Prabhakar R, Narayanan PR: IS6110 restriction fragment length polymorphism typing of clinical isolates of Mycobacterium tuberculosis from patients with pulmonary tuberculosis in Madras, South India. Tuber Lung Dis 1995;76: 550-554.

13 Radhakrishnan I, Manju YK, Kumar RA, Mundayoor S: Implications of low frequency of IS6110 in fingerprinting field isolates of $\mathrm{Myco}-$ bacterium tuberculosis from Kerala, India. J Clin Microbiol 2001;39:1683.

14 van Doorn HR, Kuijper EJ, van der Ende A, Welten AG, van Soolingen D, de Haas PE, Dankert J: The susceptibility of Mycobacterium tuberculosis to isoniazid and the $\mathrm{Arg}->$ Leu mutation at codon 463 of $k a t G$ are not associated. J Clin Microbiol 2001;39:15911594.

15 Genewein A, Telenti A, Bernasconi C, Mordasini C, Weiss S, Maurer A-M, Reider HL, Schopfer K, Bodmer T: Molecular approach to identify route of transmission of tuberculosis in the community. Lancet 1993;342:841-844.
16 Kremer K, van Soolingen D, Frothingham R, Haas WH, Hermans PWM, Martin C, Palittapongaarnpim $\mathrm{P}$, Plikaytis BB, Riley LW, Yakrus MA, Musser JM, van Embden JDA: Comparison of methods based on different molecular epidemiological markers for typing of $M y$ cobacterium tuberculosis complex strains: Interlaboratory study of discriminatory power and reproducibility. J Clin Microbiol 1999;37: 2607-2618.

17 Hermans PWM, Messadi F, Guebrexabher H, van Soolingen D, de Haas PEW, Heersma $H$, de Neeling H, Ayoub A, Portaels F, Frommel D, Zribi M, van Embden JDA: Analysis of the population structure of Mycobacterium tuberculosis in Ethiopia, Tunisia and the Netherlands: Usefulness of DNA typing for global tuberculosis epidemiology. J Infect Dis 1995; 171:1504-1513.

18 Lillbaek T, Dirksen A, Baess I, Strunge B, Thomsen VO, Andersen AB: Molecular evidence of endogenous reactivation of Mycobacterium tuberculosis after 33 years of latent infection. J Infect Dis 2002;185:401-404.

19 Behbehani N, Abal A, Al-Shami A, Enarson DA: Epidemiology of tuberculosis in Kuwait from 1965 to 1999 . Int J Tuberc Lung Dis 2002;6:465-469.

20 Geng E, Kreiswirth B, Driver C, Li J, Burzynski J, DellaLatta P, LaPaz A, Schluger NW: Changes in the transmission of tuberculosis in New York City from 1990 to 1999. N Engl J Med 2002;346:1453-1458.

-21 Niemann S, Rusch-Gerdes S, Richter E: IS6110 fingerprinting of drug-resistant $\mathrm{Myco}$ bacterium tuberculosis strains isolated in Germany during 1995. J Clin Microbiol 1997;35: 3015-3020 